\title{
RESEARCH
}

Open Access

\section{Risk factors and outcome of COVID-19 in patients with hematological malignancies}

José Luis Piñana ${ }^{1,2,36^{*}} \mathbb{0}$, Rodrigo Martino ${ }^{3}$, Irene García-García4, Rocío Parody ${ }^{5}$, María Dolores Morales ${ }^{6}$, Gonzalo Benzo ${ }^{7}$, Irene Gómez-Catalan ${ }^{8}$, Rosa Coll9, Ignacio De La Fuente ${ }^{10}$, Alejandro Luna ${ }^{4}$, Beatriz Merchán ${ }^{6}$, Anabelle Chinea ${ }^{4}$, Dunia de Miguel ${ }^{6}$, Ana Serrano $^{8}$, Carmen Pérez ${ }^{10}$, Carola Diaz $^{11}$, José Luis Lopez ${ }^{12}$, Adolfo Jesús Saez ${ }^{4}$, Rebeca Bailen ${ }^{13}$, Teresa Zudaire ${ }^{14}$, Diana Martínez ${ }^{15}$, Manuel Jurado ${ }^{16}$, María Calbacho ${ }^{17}$, Lourdes Vázquez $^{18}$, Irene Garcia-Cadenas ${ }^{3}$, Laura Fox ${ }^{19}$, Ana I. Pimentel ${ }^{20}$, Guiomar Bautista ${ }^{21}$, Agustin Nieto ${ }^{22}$, Pascual Fernandez ${ }^{23}$, Juan Carlos Vallejo ${ }^{24}$, Carlos Solano ${ }^{25}$, Marta Valero ${ }^{26}$, Ildefonso Espigado ${ }^{27}$, Raquel Saldaña ${ }^{28}$, Luisa Sisinni ${ }^{29}$, Josep Maria Ribera ${ }^{30}$, Maria Jose Jimenez ${ }^{30}$, Maria Trabazo ${ }^{31}$, Marta Gonzalez-Vicent ${ }^{32}$, Noemí Fernández ${ }^{33}$, Carme Talarn ${ }^{34}$, Maria Carmen Montoya ${ }^{8}$, Angel Cedillo ${ }^{35}$ and Anna Sureda ${ }^{5}$ on behalf of Infectious Complications Subcommittee of the Spanish Hematopoietic Stem Cell Transplantation and Cell Therapy Group (GETH)

\begin{abstract}
Background: Prognostic factors of poor outcome in patients with hematological malignancies and COVID-19 are poorly defined.

Patients and methods: This was a Spanish transplant group and cell therapy (GETH) multicenter retrospective observational study, which included a large cohort of blood cancer patients with laboratory-confirmed SARS-CoV-2 infection through PCR assays from March 1st 2020 to May 15th 2020.

Results: We included 367 pediatric and adult patients with hematological malignancies, including recipients of autologous (ASCT) $(n=58)$ or allogeneic stem cell transplantation (allo-SCT) $(n=65)$ from 41 hospitals in Spain. Median age of patients was 64 years (range 1-93.8). Recipients of ASCT and allo-SCT showed lower mortality rates $(17 \%$ and $18 \%$, respectively) compared to non-SCT patients $(31 \%)(p=0.02)$. Prognostic factors identified for day 45 overall mortality (OM) by logistic regression multivariate analysis included age $>70$ years [odds ratio (OR) $2.1,95 \%$ confidence interval (CI) 1.2-3.8, $\mathrm{p}=0.011$ ]; uncontrolled hematological malignancy (OR 2.9, 95\% Cl 1.6-5.2, $\mathrm{p}<0.0001)$; ECOG 3-4 (OR, 2.56, 95\% Cl 1.4-4.7, $\mathrm{p}=0.003)$; neutropenia $\left(<0.5 \times 10^{9} / \mathrm{L}\right)(\mathrm{OR} 2.8,95 \% \mathrm{Cl} 1.3-6.1, \mathrm{p}=0.01)$; and a C-reactive protein (CRP) $>20 \mathrm{mg} / \mathrm{dL}$ (OR 3.3, 95\% Cl 1.7-6.4, $\mathrm{p}<0.0001)$. In multivariate analysis of 216 patients with very severe COVID-19, treatment with azithromycin or low dose corticosteroids was associated with lower OM (OR $0.42,95 \% \mathrm{Cl} 0.2-0.89$ and $\mathrm{OR} 0.31,95 \% \mathrm{Cl} 0.11-0.87$, respectively, $\mathrm{p}=0.02$ ) whereas the use of hidroxycloroquine did not show significant improvement in OM (OR 0.64, 95\% Cl 0.37-1.1, $\mathrm{P}=0.1)$.
\end{abstract}

\footnotetext{
${ }^{*}$ Correspondence: jlpinana@gmail.com

${ }^{36}$ Division of Clinical Hematology, Hospital Universitario la Fe de Valencia,

Avda Fernando Abril Martorell, 106 CP 46026 Valencia, Spain

Full list of author information is available at the end of the article
}

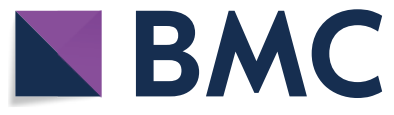

(c) The Author(s) 2020. This article is licensed under a Creative Commons Attribution 4.0 International License, which permits use, sharing, adaptation, distribution and reproduction in any medium or format, as long as you give appropriate credit to the original author(s) and the source, provide a link to the Creative Commons licence, and indicate if changes were made. The images or other third party material in this article are included in the article's Creative Commons licence, unless indicated otherwise in a credit line to the material. If material is not included in the article's Creative Commons licence and your intended use is not permitted by statutory regulation or exceeds the permitted use, you will need to obtain permission directly from the copyright holder. To view a copy of this licence, visit http://creativeco mmons.org/licenses/by/4.0/. The Creative Commons Public Domain Dedication waiver (http://creativecommons.org/publicdomain/ zero/1.0/) applies to the data made available in this article, unless otherwise stated in a credit line to the data. 
Conclusions: In most patients with hematological malignancies COVID-19 mortality was directly driven by older age, disease status, performance status, as well as by immune (neutropenia) parameters and level of inflammation (high (CRP). Use of azithromycin and low dose corticosteroids may be of value in very severe COVID-19.

\section{Background}

The coronavirus infectious disease 2019 (COVID19) pandemic caused by the new zoonotic coronavirus (SARS-CoV-2) is causing a massive impact globally. Mortality can be as high as $15 \%$ in elderly patients, and/ or in patients with comorbidities [1,2]. Risk factors for COVID-19 severity and death include older age, diabetes, hypertension, or cardiac disease [1-4]. Prior experience with seasonal community-acquired respiratory virus (CARV) infections showed that, in immunocompromised patients, these infections are notable for prolonged viral shedding, higher rates of pneumonia and mortality $[5,6]$. Thus, it would be expected that COVID-19 be particularly life threatening in patients with hematological malignancies. In fact, initial reports suggested that patients with cancer had an estimated two-fold increased risk of contracting SARS-CoV-2 than the general population and, if infected, also had a higher risk of severe events [intensive care unit (ICU) admission, invasive ventilation, or death] compared to patients without cancer [7-9]. The outcomes of COVID-19 in patients with hematological disorders such as leukemia, lymphoma, myeloma and recipients of autologous (ASCT) or allogeneic hematopoietic stem cell transplantation (allo-SCT) are of utmost interest due to their high degree of humoral and cellular immunosuppression status. Recent studies have reported an overall COVID-19 related mortality of 32 to $40 \%$ in hematological patients [10-14]. Future challenges include the identification of prognostic factors that could help in risk assessment and decision-making for effective supportive care and antiviral therapy or in cases of limited access to ICU.

The current study addresses the COVID-19 clinical course, outcome and risk factors for severe disease and mortality in a large series of patients with hematological disorders, including recipients of ASCT and allo-SCT.

\section{Patients and methods}

\section{Study population}

This is a retrospective multicenter cohort study of the Infectious Complications Subcommittee (GRUCINI) of the Spanish Hematopoietic Stem Cell Transplantation and Cell Therapy Group (GETH).

\section{Inclusion criteria and data preparation}

This series included patients (pediatric and adult) with PCR-documented SARS-CoV-2 infection diagnosed from
March 1st 2020 to May 15th 2020 in 41 participating Spanish centers. The status of all patients (and thus the study database) was updated on May 21th 2020. During the study period, hematological patients from participating centers with COVID-19 were prospectively registered through REDcap on-line platform in the GETH database by completing an essential medical data form, and more detailed baseline and outcome data were retrospectively requested afterwards with follow-up forms. The information collected included respiratory symptoms (rhinorrhea, cough, dyspnea, oxygen requirement, sinusitis, otitis, and fever), SARS-COV-2-related hospital admission, oxygen requirement, ICU admission, antiviral COVID-19 therapy given for at least 3 consecutive days, corticosteroid use and anti-cytokine therapy. The dose of corticosteroids was divided in 2 groups, $\leq$ or $>0.5 \mathrm{mg} / \mathrm{kg} /$ day of methylprednisolone (or equivalent doses of prednisone, dexamethasone or hydrocortisone). Details on the underlying disease and its treatment(s) were also captured (details not shown). Baseline laboratory variables, if available [absolute lymphocyte and neutrophil counts, C-reactive protein (CRP), IL6, ferritin and D-dimer levels], were also requested at the time or within 3 days after SARS-CoV-2 detection. Detailed microbiological findings and radiological pulmonary patterns were also required for each episode.

\section{Definitions}

We classified COVID-19 stages according to the recent published staging proposal [15]. Briefly, stage 1 refers to early establishment of disease (symptomatic infection of the upper respiratory tract only, with or without fever and generalized malaise). In stage 1 we included patients reported as being asymptomatic by the registering physician, as well as patients with upper respiratory symptoms (rhinorrhea, sinusitis, otitis, or pharyngitis) and/or systemic symptoms (fever, diarrhea, nausea or vomiting, fatigue and myalgia) in the absence of lower respiratory tract disease (LRTD) symptoms and/or any indication of pulmonary infiltrates by radiology, either chest X-ray or computed tomography (CT) scan. Stage II was divided into IIA and IIB. Stage IIA refers to patients with LRTD with radiological proof of pulmonary involvement but without requirements for oxygen support to maintain an oxygen saturation $>92 \%$. Stage IIB included patients meeting the IIA criteria but who required oxygen support (i.e., patients with acute respiratory failure). Finally, 
we did not classify cases as stage III since we did not have sufficient inflammatory blood markers in all cases, which are required for upgrading a stage IIB to a stage III. Patients with stage IIB thus comprise all patients with severe COVID-19, while stage IIA can be considered to have moderate COVID-19. We considered very severe COVID-19 those who developed stage IIB and those who required ICU admission due to respiratory failure and/or hemodynamic instability.

Disease status at the time of SARS-CoV-2 detection was defined according to each specific disease's revised criteria for leukemia, myeloproliferative neoplasm, multiple myeloma and lymphoma [16-18]. Performance status at the time of COVID-19 was graded according to the Eastern Cooperative Oncology Group (ECOG) [19]. Cardiomyopathy was defined by the patient's medical history or when the left ventricular ejection fraction was $<50 \%$, as were moderate to severe valvular disease, prior or current history of coronary artery disease, or heart failure.

\section{Technical and diagnostic considerations}

Patients with URTD and/or LRTD symptoms underwent nasopharyngeal aspiration, nasopharyngeal swabs, or an induced sputum test, while BAL was performed very rarely and only in patients with negative PCR in the upper airway with radiology-proven LRTD and whenever an alternative diagnosis for the patient was deemed possible by each treating team. Most patients underwent weekly PCR test monitoring until negativity of SARS-CoV-2, especially when the patients improved and discharge was being considered, or for epidemiological reasons. The specific method used for performing the PCR was not captured. During this pandemic, GETH published online recommendations on the diagnosis, management, testing and infectious control measures (available in the following website; https://www.geth.es/).

\section{Endpoints and statistical analysis}

The primary objective of the study was to describe clinical characteristics of COVID-19 in onco-hematological patients. We also analyzed potential risk factors (RFs) for the development of severe COVID-19 (stage IIB) and day 45 mortality after SARS-CoV-2 detection. Lastly, we explored the effect of antiviral and anti-cytokine therapy on mortality in patients with very severe COVID-19.

The main characteristics of patients were reported by descriptive statistics on the total of the available information. Median and range were used for continuous variables, while absolute and percentage frequencies were used for categorical variables. Univariate and multivariate analyses of clinical, laboratory and therapeutic variables associated with outcomes were calculated using logistic regression models. For multivariate analysis, only variables with parameter estimates showing a $\mathrm{p}$ value $\leq 0.10$ in the univariate analysis were finally included. Two-sided exact $\mathrm{P}$ values were reported and $\mathrm{p}$ values $\leq 0.05$ were considered statistically significant. COVID-19 related mortality according to different clinical and biological variables was estimated from time of SARS-CoV-2 detection using Kaplan-Meier curves and univariate comparisons were made with the log-rank test. All the analyses were performed using the statistical software SPSS v. 20.

\section{Results}

\section{Patient characteristics}

Overall, 388 pediatric and adult patients with hematological malignancies were initially registered. However, 21 cases were excluded due to negative results for SARS-CoV-2 PCR testing, irrespective of being classified as "probable COVID-19" by their hospital or regional epidemiologists based on a compatible clinical presentation and the large numbers of infections in the community. Thus, the study includes 367 patients with laboratory-confirmed SARS-CoV-2. Patient and disease characteristics according to whether they received or not a hematopoietic stem cell transplant (ASCT or allo-SCT) are detailed in Table 1 . The median age was 64 years (range 1-93.8). Overall, the most common hematological disease was non-Hodgkin's lymphoma $(n=91$, $25 \%)$ followed by plasma cell disorders $(n=81,22 \%)$. As expected, patients who did not receive SCT were older, had been diagnosed more recently of their hematological malignancy and/or had received chemotherapy less than 40 days before the SARS-CoV-2 infection, and thus they also had higher rates of uncontrolled hematological disease (not in partial or complete remission). Of note, they had higher comorbidities such as hypertension, cardiomyopathy and dyslipidemia ( $<0.01$ for all comparisons). In contrast, recipients of SCT had received more prior lines of therapy, while allo-SCT recipients were commonly receiving immunosuppressive drugs at the time of COVID-19 diagnosis ( $\mathrm{p}<0.01$ for all comparisons).

\section{Clinical characteristics of COVID-19 in non-transplant and transplant patients}

Detailed clinical and laboratory characteristics of COVID-19 by patient category (non-SCT, ASCT and allo-SCT recipients) are shown in Table 2. Most patients $(\mathrm{n}=250,68 \%)$ were diagnosed from March 19th to April 8th (see Fig. 1). Out of the 367 cases, 285 (78\%) were diagnosed in the outpatient or emergency units, and non-SCT patients were more commonly diagnosed during a hospital admission for treatment of their hematological disease or its complications ( $23 \%$ vs. $12 \%$ in SCT recipients). 
Table 1 Patient's characteristics

\begin{tabular}{|c|c|c|c|c|}
\hline Characteristics & $\begin{array}{l}\text { Hematological disease, } \\
\text { non-SCT }(n=244)\end{array}$ & $\operatorname{ASCT}(n=58)$ & Allo-SCT $(n=65)$ & $\mathrm{p}$ value \\
\hline Age (years), median (range) & $71(7-93)$ & $61(34-75)$ & $48(1-70)$ & $<0.0001$ \\
\hline $0-40$ years, $\mathrm{n}(\%)$ & $20(8)$ & $1(2)$ & $25(39)$ & $<0.0001$ \\
\hline $41-60$ years, $n(\%)$ & $51(22)$ & $22(38)$ & $21(32)$ & \\
\hline 61-70 years, $\mathrm{n}(\%)$ & $45(18)$ & $30(52)$ & (17) (26) & \\
\hline$>71$ years, $\mathrm{n}(\%)$ & $128(52)$ & $5(8)$ & $2(3)$ & \\
\hline Male, $\mathrm{n}(\%)$ & $132(54)$ & $34(59)$ & $40(61)$ & 0.5 \\
\hline Baseline disease, n (\%) & & & & $<0.0001$ \\
\hline $\mathrm{AML}$ & $44(19)$ & 0 & $23(35)$ & \\
\hline ALL & $12(5)$ & $1(2)$ & $12(18)$ & \\
\hline MDS & $12(5)$ & 0 & $10(15)$ & \\
\hline CMPD & $27(11)$ & 0 & $2(3)$ & \\
\hline $\mathrm{NHL}$ & $68(28)$ & $17(30)$ & $6(9)$ & \\
\hline $\mathrm{CLL}$ & $2(10)$ & 0 & $2(3)$ & \\
\hline Plasmatic cell disorder & $40(16)$ & $38(66)$ & $3(5)$ & \\
\hline AA or auto-immune disorders & $13(6)$ & $1(2)$ & $5(8)$ & \\
\hline Disease status, n (\%) & & & & $<0.0001$ \\
\hline CR/PR & $81(33) / 45(18)$ & $28(48) / 16(28)$ & $56(86) / 0$ & \\
\hline Not in remission (Rel/Ref/Prog) & $10(4) / 8(3) / 23(9)$ & $5(8) / 1(2) / 6(10)$ & $6(9) / 0 / 2(3)$ & \\
\hline Active disease not requiring therapy & $22(9)$ & 0 & 0 & \\
\hline \multicolumn{5}{|l|}{ Prior lines of therapy } \\
\hline $0-1$ & $189(77)$ & $21(36)$ & $26(40)$ & $<0.001$ \\
\hline$>1$ & $55(23)$ & $37(64)$ & $39(60)$ & \\
\hline \multicolumn{5}{|l|}{ Allo-SCT, n (\%) } \\
\hline HLA identical sibling & & & $29(45)$ & \\
\hline Unrelated Donor & & & $22(34)$ & \\
\hline Haplo-identical family donor & & & $14(21)$ & \\
\hline Time from transplant to COVID-19, days (range) & & $790(10-10661)$ & $441(6-7597)$ & 0.1 \\
\hline Prior therapy/conditioning 40 days before COVID-19, n (\%) & $102(42)$ & $24(41)$ & $10(15)$ & $<0.0001$ \\
\hline Disease diagnosed within 40 days of COVID-19, n (\%) & $60(25)$ & 0 & 0 & $<0.0001$ \\
\hline \multicolumn{5}{|l|}{ Under immunosuppressive drugs before COVID-19 } \\
\hline CNI or sirolimus or MMF & 0 & 0 & $28(43)$ & $<0.0001$ \\
\hline Performance status, n (\%) & & & & 0.2 \\
\hline ECOG 0-1 & $166(68)$ & $48(82)$ & $50(77)$ & \\
\hline ECOG 2/ECOG 3-4 & $45(18) / 28(11)$ & $7(12) / 2(3)$ & $7(11) / 5(8)$ & \\
\hline \multicolumn{5}{|l|}{ Pulmonary/cardiovascular risk factors, $\mathrm{n}(\%)$} \\
\hline Active smoking & $27(11)$ & $4(7)$ & $2(3)$ & 0.12 \\
\hline Arterial hypertension & $118(48)$ & $12(21)$ & $12(18)$ & $<0.0001$ \\
\hline Cardiomyopathy & $51(21)$ & $10(17)$ & $4(6)$ & 0.021 \\
\hline Dyslipidemia & $78(32)$ & $11(19)$ & $5(8)$ & $<0.0001$ \\
\hline Diabetes & $9(4)$ & $3(5)$ & $3(5)$ & \\
\hline Median F/U after COVID-19, days (range) & $21(0-74)$ & $30(0-72)$ & $35(0-72)$ & 0.2 \\
\hline Median F/U in survivors, days (range) & $33(10-74)$ & $34(11-72)$ & $40(12-72)$ & 0.2 \\
\hline
\end{tabular}

SCT: stem cell transplantation; ASCT: autologous stem cell transplantation; allo-SCT: allogeneic hematopoietic stem cell transplantation; AML: acute myeloid leukemia; ALL: acute lymphoblastic leukemia; MDS: myelodysplastic syndrome; CMPD: chronic myeloproliferative disease; NHL: non-Hodgkin lymphoma; CLL: chronic lymphocytic leukemia; AA: aplastic anemia; CR: complete remission; PR: partial remission; Rel: relapse; Ref: refractory; Prog: progression; CNI: calcineurin inhibitors; MMF: mycophenolate mophetil acid; F/U: follow-up 
Table 2 Clinical and laboratory characteristics

\begin{tabular}{|c|c|c|c|c|}
\hline Characteristics & $\begin{array}{l}\text { Hematological disease, } \\
\text { non-SCT }(n=244)\end{array}$ & $\operatorname{ASCT}(n=58)$ & Allo-HCT $(n=65)$ & $\mathrm{p}$ value \\
\hline Place of SARS-CoV-2 infection, n (\%) & & & & 0.1 \\
\hline Outpatient & $180(74)$ & $50(86)$ & $55(85)$ & \\
\hline Inpatient in specialized hospital & $55(23)$ & $7(12)$ & $8(12)$ & \\
\hline Hospice institution & $9(4)$ & $1(2)$ & $2(3)$ & \\
\hline COVID-related hospital admission, n (\%) & $163(67)$ & $42(72)$ & $44(68)$ & 0.079 \\
\hline \multicolumn{5}{|l|}{ Symptoms, n (\%) } \\
\hline Asymptomatic & $19(8)$ & $6(10)$ & $5(8)$ & 0.9 \\
\hline Fever & $178(73)$ & $40(69)$ & $41(63)$ & 0.6 \\
\hline Rhinorrhea & $29(12)$ & $11(19)$ & $14(22)$ & 0.3 \\
\hline Pharyngitis & $15(6)$ & $3(5)$ & $9(14)$ & 0.09 \\
\hline Fatigue & $140(57)$ & $24(41)$ & $32(49)$ & 0.25 \\
\hline Myalgia & $51(21)$ & $9(16)$ & $13(20)$ & 0.38 \\
\hline Cough & $175(72)$ & $30(52)$ & $39(60)$ & 0.069 \\
\hline Diarrhea & $54(22)$ & $15(26)$ & $12(18)$ & 0.5 \\
\hline Emesis & $23(9)$ & $8(14)$ & $6(9)$ & 0.46 \\
\hline \multicolumn{5}{|l|}{ COVID-19 stage ${ }^{\mathrm{a}}, \mathrm{n}(\%)$} \\
\hline Stage 1 & $41(17)$ & $15(26)$ & $18(28)$ & 0.075 \\
\hline Stage $2 \mathrm{~A}$ & $70(29)$ & $22(38)$ & $19(29)$ & 0.38 \\
\hline Stage 2B & $133(55)$ & $21(36)$ & $28(43)$ & 0.027 \\
\hline Oxygen support, n (\%) & $136(56)$ & $24(41)$ & $32(49)$ & 0.021 \\
\hline Abnormal radiological pulmonary finding, $\mathrm{n}(\%)$ & $200(82)$ & $44(76)$ & $46(71)$ & 0.35 \\
\hline Antiviral COVID-19 therapy, n (\%) & & & & 0.05 \\
\hline None & $49(20)$ & $16(28)$ & $13(20)$ & \\
\hline $\mathrm{HCQ}$ & $15(6)$ & 0 & $11(17)$ & \\
\hline $\mathrm{HCQ}+\mathrm{AZT}$ & $36(15)$ & $5(9)$ & $8(12)$ & \\
\hline $\mathrm{HCQ}+\mathrm{AZT}+$ lop/rit & $14(5)$ & $3(5)$ & $1(1)$ & \\
\hline lop/rit & $29(12)$ & $4(9)$ & $5(8)$ & \\
\hline HCQ + lop/rit & $32(13)$ & $14(24)$ & $8(12)$ & \\
\hline$A Z T+l o p / r i t$ & $39(16)$ & $6(12)$ & $8(12)$ & \\
\hline $\mathrm{AZT}$ & $24(10)$ & $5(7)$ & $7(11)$ & \\
\hline Remdesivir & $3(1)$ & $3(5)$ & $2(3)$ & \\
\hline Other & $4(2)$ & $3(5)$ & $3(5)$ & \\
\hline Corticosteroid therapy & & & & 0.029 \\
\hline No & $132(54)$ & $40(69)$ & $45(69)$ & \\
\hline$\leq 0.5 \mathrm{mg} / \mathrm{kg} / \mathrm{day}^{\mathrm{b}}$ & $29(12)$ & $7(12)$ & $9(14)$ & \\
\hline$>0.5 \mathrm{mg} / \mathrm{kg} / \mathrm{day}^{\mathrm{b}}$ & $83(34)$ & $11(19)$ & $11(17)$ & \\
\hline \multicolumn{5}{|l|}{ Anti-cytokine supportive therapy, n (\%) } \\
\hline Tocilizumab & $26(11)$ & $10(17)$ & $14(21)$ & 0.05 \\
\hline Anakinra & $10(4)$ & $3(5)$ & $5(8)$ & \\
\hline Baricitinib & $6(2)$ & $1(2)$ & 0 & \\
\hline \multicolumn{5}{|c|}{ Laboratory characteristics at the time of SARS-CoV-2 detection } \\
\hline ANC $<0.5 \times 10^{9} / \mathrm{L}, \mathrm{n}(\%)$ & $36(15)$ & $4(7)$ & $4(6)$ & 0.089 \\
\hline $\mathrm{ALC}<0.5 \times 10^{9} / \mathrm{L}, \mathrm{n}(\%)$ & $99(41)$ & $22(38)$ & $19(29)$ & 0.27 \\
\hline Platelet count $\left(\times 10^{9} / L\right)$, median (range) & $109(1-1075)$ & $127(5-410)$ & $115(10-548)$ & 0.4 \\
\hline$<20 \times 10^{9} / \mathrm{L}$ & $28(13)$ & $2(4)$ & $4(7)$ & \\
\hline $21-50 \times 10^{9} / \mathrm{L}$ & $27(12)$ & $7(14)$ & $9(15)$ & \\
\hline$>50 \times 10^{9} / \mathrm{L}$ & $166(75)$ & $42(82)$ & $46(78)$ & \\
\hline CRP > 20 mg/dL (n/evaluable, \%) & $152 / 217(70)$ & 23/48 (48) & $25 / 54(46)$ & 0.001 \\
\hline IL-6 > 50 pg/mL (n/evaluable, \%) & $28 / 70(40)$ & $6 / 15(40)$ & $11 / 25(44)$ & 0.9 \\
\hline
\end{tabular}


Table 2 (continued)

\begin{tabular}{|c|c|c|c|c|}
\hline Characteristics & $\begin{array}{l}\text { Hematological disease, } \\
\text { non-SCT }(n=244)\end{array}$ & ASCT $(n=58)$ & Allo-HCT $(n=65)$ & $\mathrm{p}$ value \\
\hline Ferritin > 500 g/mL, (n/evaluable, \%) & $80 / 104(77)$ & $14 / 21(67)$ & $25 / 29(86)$ & 0.4 \\
\hline D dimer $>500$ ng/mL (n/evaluable, \%) & $127 / 197(64)$ & 20/42 (48) & $25 / 46(54)$ & 0.085 \\
\hline Recovery from COVID-19 (n/evaluable, \%) & 107/218 (49) & $42 / 57(74)$ & $33 / 59(56)$ & 0.001 \\
\hline PCR negativity documented (n/evaluable, \%) & 49/131 (37) & $15 / 30(50)$ & $13 / 27(48)$ & 0.01 \\
\hline Median time from diagnosis to negativity, days (range) & $20(4-48)$ & $26(7-53)$ & $26(7-43)$ & 0.5 \\
\hline Overall mortality, n (\%) & $80(33)$ & $12(21)$ & $13(20)$ & 0.1 \\
\hline COVID-19 related mortality, n (\%) & $76(31)$ & $10(17)$ & $12(18)$ & 0.02 \\
\hline Median time from diagnosis to death, days (range) & $7.5(0-38)$ & $13(0-51)$ & $8(0-42)$ & 0.18 \\
\hline Admission to the ICU, n (\%) & $28(11)$ & $8(14)$ & $7(11)$ & 0.8 \\
\hline ICU mortality rate, $\mathrm{n}(\%)$ & $16(57)$ & $2(25)$ & $3(43)$ & 0.2 \\
\hline
\end{tabular}

SCT: stem cell transplantation; ASCT: autologous stem cell transplantation; allo-SCT: allogeneic hematopoietic stem cell transplantation; HCQ: hydroxi-cloroquine; AZT: azithromycin; lop/rit, lopinavir/ritonavir; ANC: absolute neutrophil count; ALC: absolute lymphocyte count; CRP: C-reactive protein; IL: interleukin; PCR: polymerase chain reaction; ICU: intensive care unit

${ }^{\text {a }}$ As suggested in Siddiqi et al. [15]

b Refers to dose of IV methylprednisolone or an equivalent dose of another corticosteroid

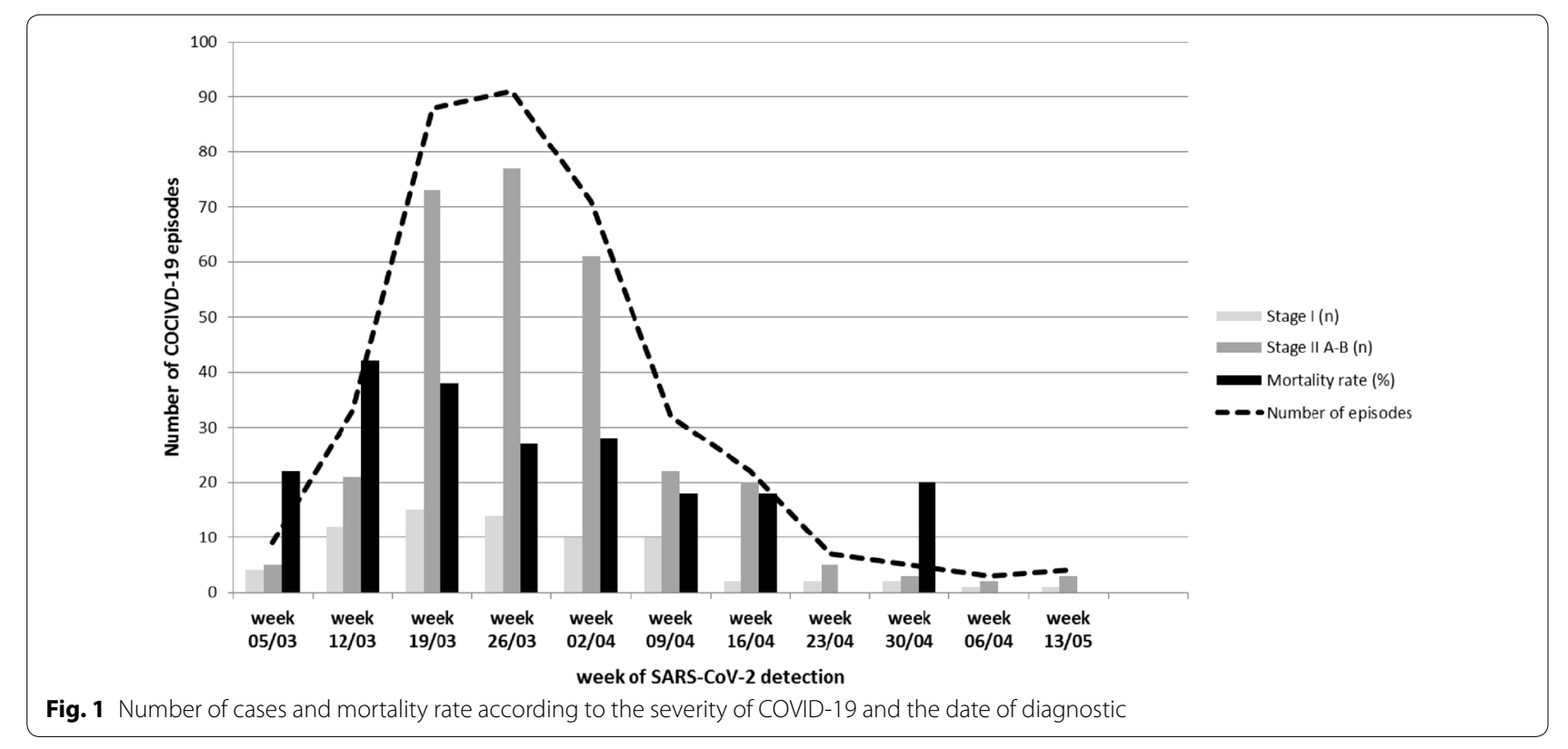

During follow-up, 30 patients (8\%) who were asymptomatic at the time SARS-CoV-2 infection was made did not develop symptoms during follow-up (no differences by patient type). Otherwise, the most common clinical features were fever $(\mathrm{n}=259,71 \%)$ cough $(\mathrm{n}=244,66 \%)$, fatigue $(\mathrm{n}=192,53 \%)$ and diarrhea $(\mathrm{n}=81,22 \%)$. COVID-19 was in stage $\mathrm{I}$ in 74 cases $(20 \%)$, stage IIA in 111 patients (30\%) and stage IIB in 182 cases $(50 \%)$. We did not observe significant variations in clinical symptoms among groups. Although pulmonary involvement was not significantly different amongst groups $(83 \%, 74 \%$ and $72 \%$ of non-SCT, ASCT and allo-SCT, respectively, $\mathrm{p}=0.2$ ), non-SCT and alloSCT patients had higher rates of acute respiratory failure (stage IIB) than ASCT (55\% vs. $48 \%$ vs. $36 \%$, respectively, $\mathrm{p}=0.027$ ).

Regarding the available laboratory data, nonSCT patients had higher rates of severe neutropenia $\left(<0.5 \times 10^{9} / \mathrm{mL}\right)$ and high CRP $(>20 \mathrm{mg} / \mathrm{dL})$ as compared to ASCT and allo-SCT $(\mathrm{p}<0.0001)$, whereas high IL-6, ferritin and D-dimer levels were similar among groups, although these latter laboratory values were available in less than half of the patients (see Table 2). 


\section{Outcome and mortality}

The overall median follow-up after SARS-CoV-2 infection was 25 days (range 0-74) for the entire cohort (see Table 1). At the time of the last follow-up, centers reported a higher proportion of full clinical recovery from COVID-19 in ASCT recipients (74\%) as compared to allo-SCT (56\%) and non-SCT patients (48\%) $(\mathrm{p}<0.0001)$. The proportion of documented SARSCoV-2 PCR negativity during follow-up screening was also higher in SCT patients (ASCT $50 \%$ and allo-SCT $48 \%)$ as compared to non-SCT $(37 \%)(\mathrm{p}=0.01)$ without any significant differences in time to negativity (see Table 2).

Overall mortality at day 45 after SARS-CoV-2 detection was $29 \% \quad(\mathrm{n}=105)$, whereas day 45 COVID-19-related mortality was $27 \%(n=98)$. The COVID-19-related mortality was higher in non-SCT (31\%) as compared to ASCT (17\%) and allo-SCT (18\%) $(\mathrm{p}=0.02)$. Median time to death was similar among groups (see Table 2). Overall mortality in patients who were considered suitable candidates for the ICU $(n=43)$ was high $(n=21,49 \%)$ without differences between groups. Overall mortality rate according to the date of COVID-19 diagnosis is shown in Fig. 1. Overall mortality according to the COVID-19 stage in the entire cohort and by patient groups is shown in Fig. $2 \mathrm{a}-\mathrm{d}$.

\section{Risk factors for severe COVID-19 (stage IIB) and mortality}

Logistic regression univariate and multivariate analyses of conditions associated with COVID-19 stage IIB and related mortality in all 367 patients are shown in Table 3.

By multivariate analysis we identified 3 conditions associated with stage IIB or severe COVID-19; history of hypertension [Odds ratio (OR) 2, 95\% confidence interval (CI) $1.3-3.2, \mathrm{p}=0.02]$, baseline lymphopenia $\left(<0.5 \times 10^{9} /\right.$ $\mathrm{mL}$ ) (OR 1.7, 95\% CI 1.1-2.7, $\mathrm{p}=0.015$ ) and baseline CRP $>20 \mathrm{mg} / \mathrm{dL}$ (OR 2.67, 95\% CI 1.6-4.3, p < 0.0001).

Finally, 5 conditions were associated with increased COVID-19-related mortality: (i) age $>70$ years (OR 2.1, 95\% CI 1.2-3.8, $\mathrm{p}=0.011$ ); (ii) uncontrolled hematological disease (OR 2.9, 95\% CI 1.6-5.2, $\mathrm{p}<0.0001$ ); (iii) ECOG 3-4 (OR, 2.56, 95\% CI 1.4-4.7, $\mathrm{p}=0.003$ ); (iv) neutropenia $\left(<0.5 \times 10^{9} / \mathrm{L}\right) \quad(\mathrm{OR} 2.8,95 \%$ CI 1.3-6.1, $\mathrm{p}=0.01)$; and (v) CRP $>20 \mathrm{mg} / \mathrm{dL}(\mathrm{OR} 3.3,95 \%$ CI $1.7-$ $6.4, \mathrm{p}<0.0001)$. Mortality rates progressively increased according to the presence of $0-1,2$ or $>2$ of these 5 RFs, as shown in Fig. 3a. Rising mortality by number of RFs was also observed in patients with stages IIA-IIB only, in patients with or without uncontrolled malignancy, and in non-SCT patients or SCT recipients (shown in Fig. 3b-f).
Effect of anti-viral and anti-cytokine supportive therapy on day 45 COVID-19-related mortality

Most patients $(\mathrm{n}=289,79 \%)$ received therapy against SARS-CoV-2, with azithromycin $(n=156,42 \%)$ and hidroxycloroquine $(n=147,40 \%)$ being the most common agents prescribed (details are shown in Table 2). However, each center established its own treatment algorithms, which also probably varied on a patient by patient basis according to the stage and progression of COVID19. Unfortunately, we did not capture the exact date of start and end of these therapeutic interventions. Thus, in order to evaluate the potential effect of therapy, we performed a second multivariate analysis of COVID-19-related mortality including only the 216 patients (59\%) with very severe disease. Results of these univariate and multivariate analyses are shown in Table 4.

Treatments which led to lower mortality in multivariate analysis were (i) the use of azithromycin (OR $0.42,95 \%$ CI $0.2-0.89, \mathrm{p}=0.02$ ), and (ii) the use of corticosteroids at doses $\leq 0.5 \mathrm{mg} / \mathrm{kg} /$ day (OR 0.31, 95\% CI 0.11-0.87, $\mathrm{p}=0.02)$; higher doses of corticosteroids ( $>0.5 \mathrm{mg} / \mathrm{kg} /$ day) did not show any effect on mortality. Of note, the use of hidroxycloroquine did not show significant improvement in OM. Other variables associated with higher mortality in this subset analysis of severely ill patients were; (iii) age $>70$ years (OR 2.54, 95\% CI 1.2-5.2, $\mathrm{p}=0.011$ ); (iv) uncontrolled hematological disease (OR 3.5, 95\% CI 1.6-7.5, $\mathrm{p}=0.001$ ); (v) platelet count $\leq 20 \times 10^{9} / \mathrm{L}(\mathrm{OR}, 5.66,95 \%$ CI $1.44-22, \mathrm{p}=0.013)$; (vi) platelet count $21-0 \times 10^{9} / \mathrm{L}$ (OR 3.3, 95\% CI 1.2-9.2, $\mathrm{p}=0.021$ ); (vii) history of arterial hypertension (OR, 2, 95\% CI 1.3-3.2, $\mathrm{p}=0.002$ ); and (viii) $\mathrm{CRP}>20 \mathrm{mg} / \mathrm{dL}$ (OR 2.7, 95\% CI 1.1-6.5, $\mathrm{p}=0.029$ ).

\section{Discussion}

We report herein a real-life experience with COVID19 diagnosed in a large number of Hematology units in Spain over a two-month period during the first pandemic wave of the SARS-CoV-2 infection. Our results show an overall mortality rate at day 45 after diagnosis of $29 \%$ (27\% COVID-19-related according to the treating physicians). Of note, a lower mortality was seen in recipients of a SCT (including allo-SCT recipients) as compared to non-SCT patients.

For its simplicity and the ability to classify cases into moderate or severe cases of pneumonia, we used the COVID-19 stages classification, as developed by Siddiqi et al. [15], and as expected found that stage IIB (pneumonia with acute respiratory failure) significantly correlated with higher mortality (shown in different study groups in Fig. 1a-d). This easy-to-implement classification could be of value for future observational studies and for the design of future randomized clinical trials. 
a In the entire cohort, according to the COVID-19 stage, mortality was $8 \%$ in patients with stage I, $18 \%$ in those with stage IIA and $53 \%$ in those who evolved to stage IIB $((\mathrm{p}<0.0001)$.

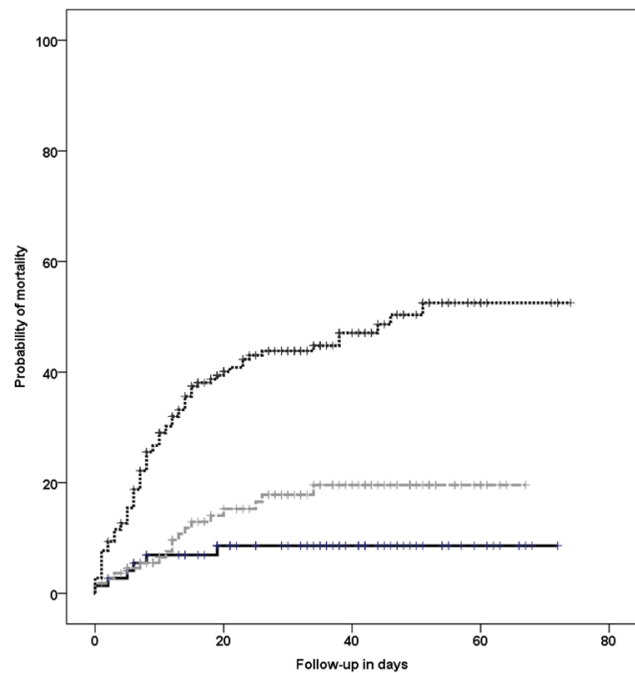

c Mortality in autologous SCT recipients was $13 \%, 11 \%$ and $50 \%$ in patients with stage I, stage IIA and Stage IIB, respectively $(p<0.09)$.

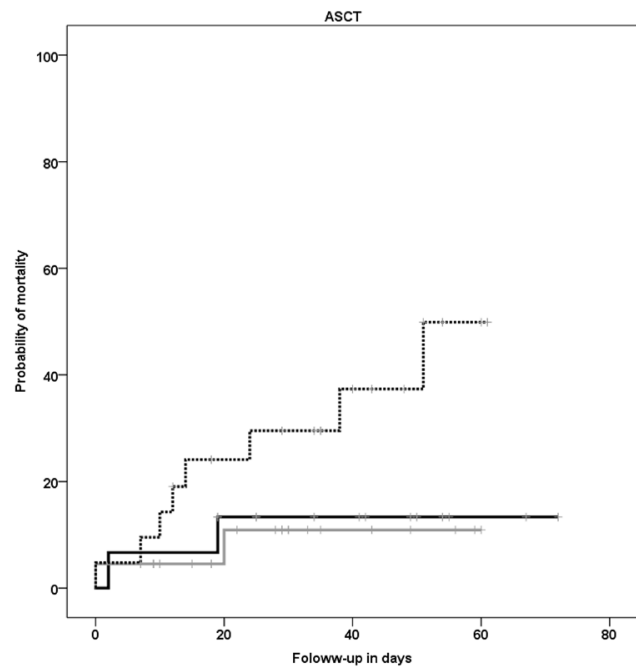

b Mortality rate in non-SCT patients was $10 \%$ vs. $23 \%$ vs. $53 \%$ in patients with stage I, stage IIA and Stage IIB, respectively $(p<0.0001)$

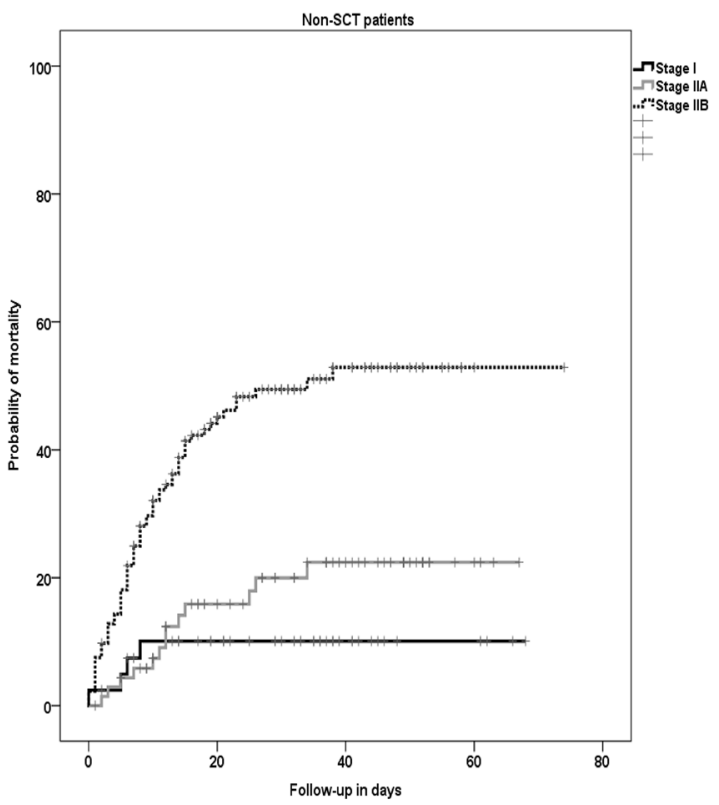

d Mortality in allo-SCT recipients was $0 \%, 17 \%$ and $47 \%$ in patients with stage I, stage IIA and Stage IIB, respectively $(\mathrm{p}<0.01)$.

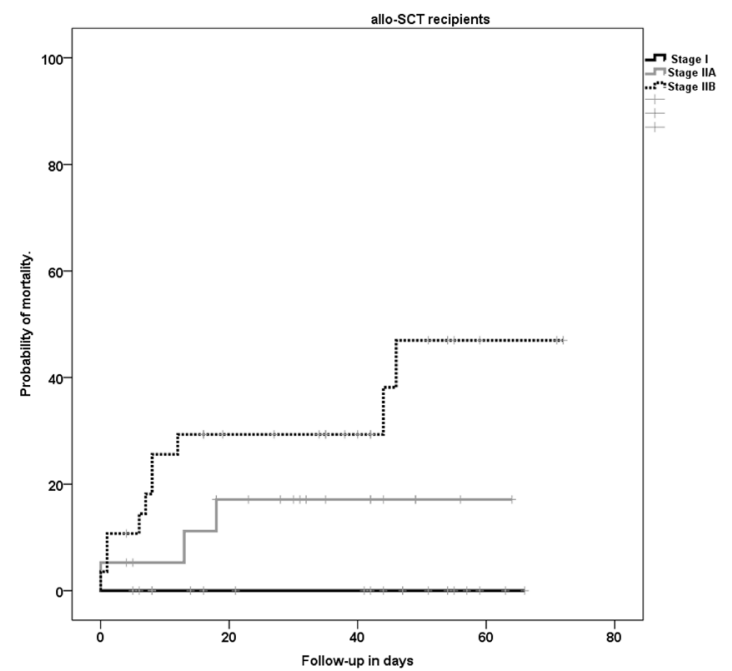

Fig. 2 Day 45 overall mortality. a In the entire cohort, according to the COVID-19 stage, mortality was $8 \%$ in patients with stage I, $18 \%$ in those with stage IIA and 53\% in those who evolved to stage IIB ( $(p<0.0001)$. b Mortality rate in non-SCT patients was $10 \%$ vs. $23 \%$ vs. $53 \%$ in patients with stage I, stage IIA and Stage IIB, respectively $(p<0.0001)$. c Mortality in autologous SCT recipients was 13\%, 11\% and 50\% in patients with stage I, stage $\| \mathrm{A}$ and Stage IIB, respectively $(\mathrm{p}<0.09)$. d Mortality in allo-SCT recipients was $0 \%, 17 \%$ and $47 \%$ in patients with stage I, stage IIA and Stage IIB, respectively $(p<0.01)$

Additionally, we found that hypertension, lymphopenia and high CRP predicted for the development of stage IIB COVID-19. Although hypertension and lymphopenia were not found to independently increase mortality in our study, both variables have been shown to be strong predictors of mortality in the general population and we can thus postulate that with larger patient numbers they would also have had an impact on survival. On the other hand, higher mortality was linked with age $>70$ years, uncontrolled hematological malignancy, baseline poor 
Table 3 Univariate and multivariate analysis of risk factors for stage IIB COVID-19 and COVID-19-related mortality

\begin{tabular}{|c|c|c|c|c|c|c|c|c|}
\hline \multirow[t]{3}{*}{ Variables } & \multicolumn{4}{|c|}{ Log. Regr. COVID-19 Stage II $B^{a}(n=367)$} & \multicolumn{4}{|c|}{ Log. Regr. COVID-19 Mortality $(n=367)$} \\
\hline & \multicolumn{2}{|c|}{ Univariate analysis } & \multicolumn{2}{|c|}{ Multivariate analysis } & \multicolumn{2}{|c|}{ Univariate analysis } & \multicolumn{2}{|c|}{ Multivariate analysis } \\
\hline & OR $(95 \% \mathrm{Cl})$ & $\mathbf{p}$ & OR $(95 \% \mathrm{Cl})$ & $\mathbf{p}$ & OR $(95 \% \mathrm{CI})$ & $\mathbf{p}$ & $\mathrm{R}(95 \% \mathrm{Cl})$ & $\mathrm{p}$ value \\
\hline Patient age $>70$ years old & $2.25(1.45-3.5)$ & $<0.0001$ & ns & & $3.1(1.9-5)$ & $<0.0001$ & $2.1(1.2-3.8)$ & 0.011 \\
\hline Patient age & & & ns & & & & ns & \\
\hline $0-20$ & 1 & & & & 1 & & & \\
\hline $21-70$ & $5.6(1.2-25)$ & 0.02 & & & $0.7(0.22-2.3)$ & 0.59 & & \\
\hline$>70$ & $11.5(2.5-52)$ & 0.002 & & & $2.3(0.7-7.5)$ & 0.16 & & \\
\hline Sex male & $1.41(0.93-2.1)$ & 0.09 & ns & & $0.95(0.6-1.5)$ & 0.8 & & \\
\hline Baseline disease & & & ns & & & & ns & \\
\hline AML & 1 & & & & 1 & & & \\
\hline ALL & $0.8(0.3-2)$ & 0.68 & & & $0.6(0.22-1.67)$ & 0.3 & & \\
\hline MDS & $1.3(0.5-3.4)$ & 0.5 & & & $0.69(0.25-1.9)$ & 0.47 & & \\
\hline CMPD & $2.7(1.1-6.8)$ & 0.032 & & & $0.6(0.23-1.5)$ & 0.3 & & \\
\hline $\mathrm{NHL}$ & $1.37(0.7-2.6)$ & 0.3 & & & $0.63(0.3-1.2)$ & 0.3 & & \\
\hline CLL & $2.9(1.12-7.6)$ & 0.03 & & & $0.7(0.35-1.06)$ & 0.06 & & \\
\hline Plasmatic cell disorder & $0.98(0.5-1.8)$ & 0.9 & & & $0.7(0.35-1.4)$ & 0.3 & & \\
\hline AA or auto-immune disorders & $0.3(0.09-1.1)$ & 0.07 & & & $0.08(0.01-0.69)$ & 0.02 & & \\
\hline Disease status & & & ns & & & & & \\
\hline $\mathrm{CR} / \mathrm{PR} /$ not requiring therapy & 1 & & & & 1 & & & \\
\hline Rel/Ref/Prog & $1.49(0.96-2.3)$ & 0.076 & & & $3.78(2.3-6)$ & $<0.0001$ & $2.9(1.6-5.2)$ & $<0.0001$ \\
\hline Procedure & & & ns & & & & ns & \\
\hline Allo-SCT & 1 & & & & 1 & & & \\
\hline $\mathrm{ASCT}$ & $0.75(0.37-1.5)$ & 0.4 & & & $1.04(0.43-2.5)$ & 0.9 & & \\
\hline Non-SCT & $1.57(0.92-2.6)$ & 0.09 & & & $1.95(1.03-3.7)$ & 0.048 & ns & \\
\hline Chemotherapy 40 days before COVID-19 & $1.18(0.7-1.8)$ & 0.4 & ns & & $1.76(1.1-2.79)$ & 0.016 & ns & \\
\hline Disease Dx within 40 days of COVID-19 & $1.1(0.6-1.9)$ & 0.7 & ns & & $2.2(1.24-3.9)$ & 0.007 & ns & \\
\hline ECOG 3-4 & $1.8(1.14-2.98)$ & 0.012 & ns & & $3.7(2.2-6.1)$ & $<0.0001$ & $2.56(1.4-4.7)$ & 0.003 \\
\hline Active smoking & $1.88(0.89-3.9)$ & 0.094 & ns & & $1.3(0.6-2.79)$ & 0.4 & & \\
\hline Arterial hypertension & $2.26(1.4-3.49)$ & $<0.0001$ & $2(1.3-3.2)$ & 0.002 & $2.6(1.6-4.16)$ & $<0.0001$ & ns & \\
\hline Cardiomyopathy & $1.98(1.1-3.4)$ & 0.015 & ns & & $1.6(0.9-2.88)$ & 0.089 & ns & \\
\hline Dyslipidemia & $1.6(1-2.59)$ & 0.049 & ns & & $1.86(1.1-3)$ & 0.015 & ns & \\
\hline Place of SARS-CoV-2 infection & & & ns & & & & & \\
\hline Outpatient & 1 & & & & 1 & & & \\
\hline Inpatient in specialized hospital & $1.1(0.6-1.8)$ & 0.69 & & & $1.05(0.3-3.6)$ & 0.9 & & \\
\hline $\mathrm{ALC}<0.5 \times 10^{9} / \mathrm{L}$ & $1.7(1.1-2.68)$ & 0.014 & $1.7(1.1-2.7)$ & 0.015 & $2.25(1.6-3.6)$ & 0.001 & ns & \\
\hline ANC $<0.5 \times 10^{9} / \mathrm{L}$ & $1.4(0.7-2.7)$ & 0.27 & ns & & $3.4(1.8-6.67)$ & $<0.0001$ & $2.8(1.3-6.1)$ & 0.01 \\
\hline Platelet count $\left(\times 10^{9} / \mathrm{L}\right)$ & & & & & & & ns & \\
\hline$<20 \times 10^{9} / \mathrm{L}$ & $1.7(0.8-3.66)$ & 0.16 & & & $4.44(2.1-9.4)$ & $<0.0001$ & & \\
\hline $21-50 \times 10^{9} / \mathrm{L}$ & $1.18(0.6-2.26)$ & 0.6 & & & $3.6(1.8-7.05)$ & $<0.0001$ & & \\
\hline$>50 \times 10^{9} / \mathrm{L}$ & 1 & & & & 1 & & & \\
\hline $\mathrm{CRP}>20 \mathrm{mg} / \mathrm{dL}$ & $3.1(1.9-4.9)$ & $<0.0001$ & $2.67(1.6-4.3)$ & $<0.0001$ & $4(2.2-7.18)$ & $<0.0001$ & $3.3(1.7-6.4)$ & $<0.0001$ \\
\hline $\mid \mathrm{L}-6>50 \mathrm{pg} / \mathrm{mL}^{\mathrm{b}}$ & $3.2(1.38-7.35)$ & 0.007 & NT & & $2.7(1.1-6.59)$ & 0.028 & NT & \\
\hline Ferritin levels ${ }^{b}$ & & & NT & & & & NT & \\
\hline$<500 \mu \mathrm{g} / \mathrm{mL}$ & 1 & & & & 1 & & & \\
\hline $501-1000 \mu \mathrm{g} / \mathrm{mL}$ & $1.18(0.4-3.2)$ & & & & $1(0.24-4.1)$ & 0.99 & & \\
\hline$>1001 \mu \mathrm{g} / \mathrm{mL}$ & $2.4(1.1-5.35)$ & 0.03 & & & $2.8(1-7.9)$ & 0.05 & & \\
\hline $\mathrm{D}$ dimer $>500 \mathrm{ng} / \mathrm{mL}^{\mathrm{b}}$ & $1.6(1.02-2.6)$ & 0.04 & NT & & $1.34(0.8-2.3)$ & 0.2 & NT & \\
\hline
\end{tabular}

SCT: stem cell transplantation; ASCT: autologous stem cell transplantation; allo-SCT: allogeneic hematopoietic stem cell transplantation; AML: acute myeloid leukemia; ALL: acute lymphoblastic leukemia; MDS: myelodysplastic syndrome; CMPD: chronic myeloproliferative disease; NHL: non-Hodgkin lymphoma; CLL: chronic lymphocytic leukemia; AA: aplastic anemia; CR: complete remission; PR: partial remission; Rel: relapse; Ref: refractory; Prog: progression; Dx: diagnostic; ANC: absolute neutrophil count; ALC: absolute lymphocyte count; CRP: C-reactive protein; IL: interleukin; ns: not significant; NT: not tested

a Stage IIB refers to severe disease, with pulmonary involvement and acute respiratory failure, as suggested in Siddiqi et al. [15]

b These variables were not included in the multivariate analyses due to the low number of patients with complete data 


\section{(See figure on next page.)}

Fig. 3 COVID-19-related mortality according to the presence of 0-1, 2 and > 2 risk factors. a In the entire cohort. Mortality rate was $18 \%$ vs. 35\% vs. $54 \%$, respectively $(p<0.0001)$. b In patients with lower respiratory involvement (stages IIA and IIB), the mortality was $22 \%$ vs. $40 \%$ vs. $58 \%$, respectively $(p<0.0001)$. $\mathbf{c}$ In patients with uncontrolled hematological malignancy at the time of COVID-19 the mortality was $33 \%$ vs. $63 \%$ vs. $80 \%$, respectively $(p<0.0001)$. $\mathbf{d}$ In patients with controlled hematological disease at the time of COVID- 19 the mortality was $7 \%$ vs. $22 \%$ vs. $44 \%$, respectively $(p<0.0001)$. e In stem cell transplant $(S C T)$ recipients the mortality was $17 \%$ vs. $34 \%$ vs. $56 \%$, respectively $(p<0.0001)$. f In non-stem cell transplant (SCT) patients the mortality was $19 \%$ vs. $34 \%$ vs. $54 \%$, respectively $(p<0.0001)$

performance status, baseline severe neutropenia and a high CRP. With these RFs, we built a simple prognostic score based on the presence of $0-1,2$ or $>2$ RFs, which clearly segregated the day 45 mortality into 3 groups. This segregation was obvious in the overall population [low risk ( $18 \%$ mortality), moderate risk (35\% mortality) and high-risk (54\% mortality); Fig. 2a], and also when tested separately in patients with pneumonia (Fig. 2b), in patients with uncontrolled or controlled underlying disease (Figs. 2c, d) and in SCT recipients as well as non-SCT patients (Fig. 2e, f). The lowest mortality was observed in patients with controlled hematological disease and without RFs (7\%) in contrast to that observed in patients with uncontrolled hematological disease with $>2$ RFs $(80 \%)$. Of course, as with any risk score obtained form a single study, its validation and improvement in independent patient cohorts is required before one can suggest that it should be used to better predict the outcome of COVID-19 in patients with hematological malignancies.

Characteristics of COVID-19 symptoms in hematological patients share similarities with the general population [20], with fever, dry cough, fatigue and diarrhea being the most common initial signs/symptoms of infection. Systemic symptoms, however, were more common than URTD symptoms, as has also been reported in the general population. Compared to non-immunosuppressed patients [3], SARS-CoV-2 shedding in the upper airway seemed longer in our series (median of 24 days) with long-lasting shedding ( $>21$ days) in a significant proportion of studied cases (55\%). The immunodeficiency driven by hematological malignancies and/or their treatment may explain a longer time for virus clearance. In the general population, low circulating $B$ cell counts have been correlated with prolonged viral shedding [21]. In spite of the immunosuppressed status, the proportion of asymptomatic patients (8\%) in our cohort was not irrelevant. Although our study was not designed to identify asymptomatic SARS-CoV-2 infections in our patients, it is obvious that these do exist, even if possibly at a lower rate than in the general population (reported to be approximately $30 \%$ of all infections) [22-26]. These observations support the recommendations for screening of SARS-CoV-2 infection in asymptomatic hematological patients before any scheduled treatments, including a planned SCT procedure, at least while the incidence in the community remains high.

In contrast with infections by other CARVs in hematological patients [27], the proportion of patients who develop LRTD when infected by SARS-CoV-2 appeared to be very high (79\%), albeit this propensity for causing pneumonia has been well described in the general population [3]. In fact, the RFs we found for the development of severe COVID-19 pneumonia (stage IIB) were similar to those reported in the general population [3]. Hypertension [3, 4, 28, 29], lymphopenia [30-33] and high blood levels of markers of inflammation (including CRP) [34-36] are among these reported RFs. Due to the lack of data in up to half of our patients, we were unable to analyze the impact of other inflammatory/procoagulant biomarkers, such as ferritin, IL-6 and D-dimer on the risk of developing severe pneumonia and death, although they did show a clear trend in univariate analysis (as shown in Table 2).

The day 45 overall and COVID-19-related mortality in this series ( $29 \%$ and $27 \%$, respectively) was comparable to other series of hematological patients [10-12], apparently higher than patients with solid tumors (13\%) [37] and much higher than in the general population $(2.3 \%)$ [38]. Somewhat surprising, however, was the lower mortality observed in SCT recipients, a patient group usually linked to the highest risk of death from opportunistic infections, including those caused by other CARV. However, patients who receive a SCT, especially an allo-SCT, are by definition younger and healthier than the overall onco-hematological patients. In fact, in our cohort we observed that most of conditions associated with higher overall mortality in multivariate analysis (i.e. older age, hypertension, uncontrolled hematological disease and high levels of CRP) were overrepresented in the non-SCT cohort, which may explain in part the lower mortality observed in SCT recipients. The fact that all patients with hematological malignancies were registered in the current study, without the strict inclusion criteria used in prospective treatment protocols and, especially, in clinical trials and for receiving a SCT, creates a much more real-life scenario. Indeed, clinicians are well accustomed to seeing elderly patients with 
Piñana et al. Exp Hematol Oncol

(2020) 9:21

Page 11 of 16

a In the entire cohort. Mortality rate was $18 \%$ vs. $35 \%$ vs. $54 \%$, respectively $(p<0.0001)$

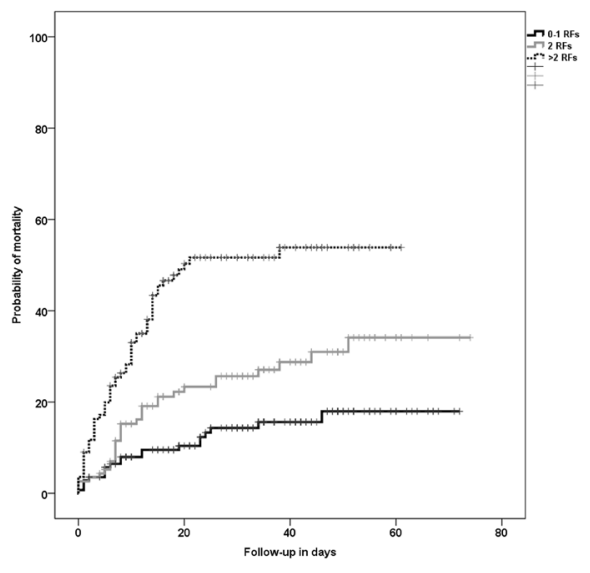

c In patients with uncontrolled hematological malignancy at the time of COVID -19 the mortality was $33 \%$ vs. $63 \%$ vs. $80 \%$, respectively ( $<<$ 0.0001 )

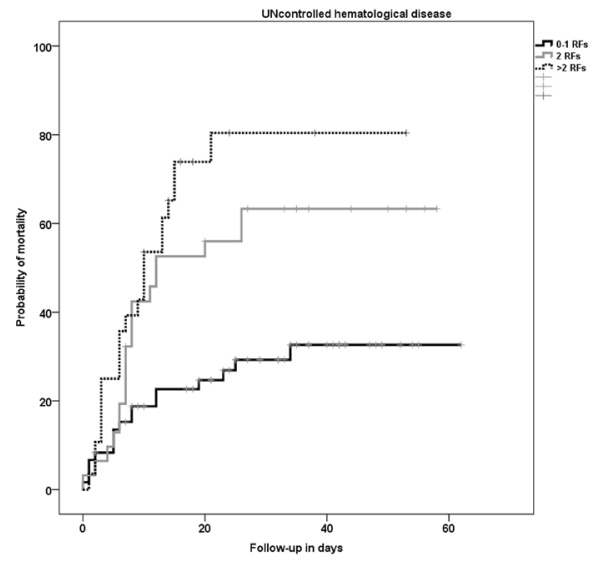

e In stem cell transplant (SCT) recipients the mortality was $17 \%$ vs. $34 \%$ vs. $56 \%$, respectively $(\mathrm{p}<0.0001)$

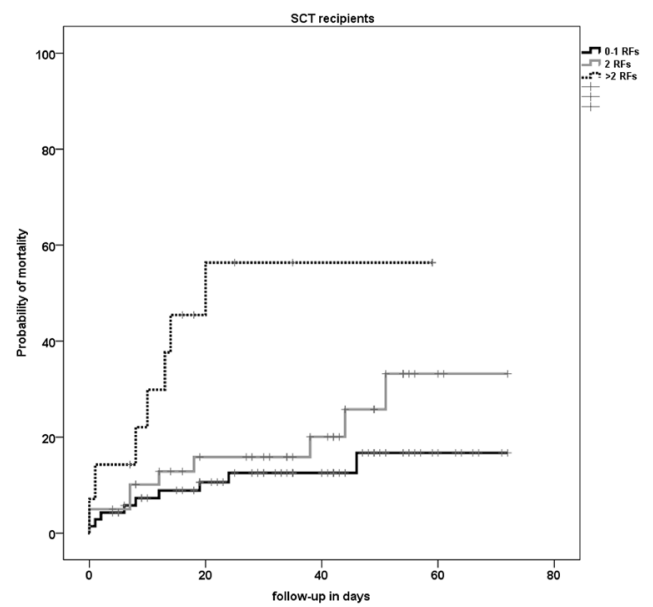

b In patients with lower respiratory involvement (stages IIA and IIB), the mortality was $22 \%$ vs. $40 \%$ vs. $58 \%$, respectively ( $p<0.0001$ )

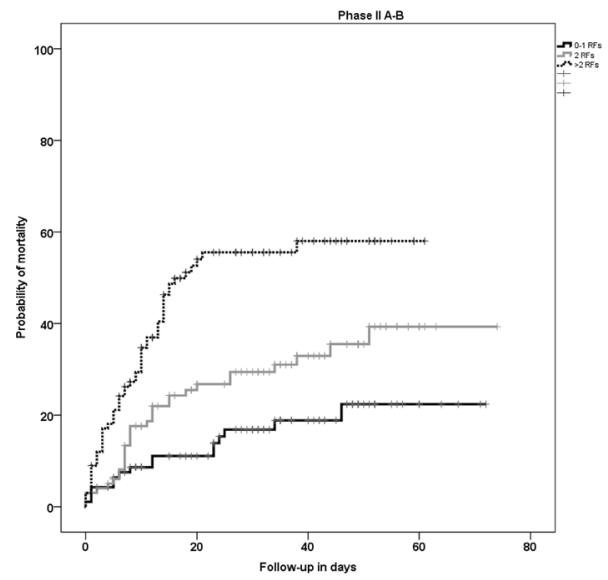

d In patients with controlled hematological disease at the time of COVID-19 the mortality was $7 \%$ vs. $22 \%$ vs. $44 \%$, respectively ( $<<0.0001$ )

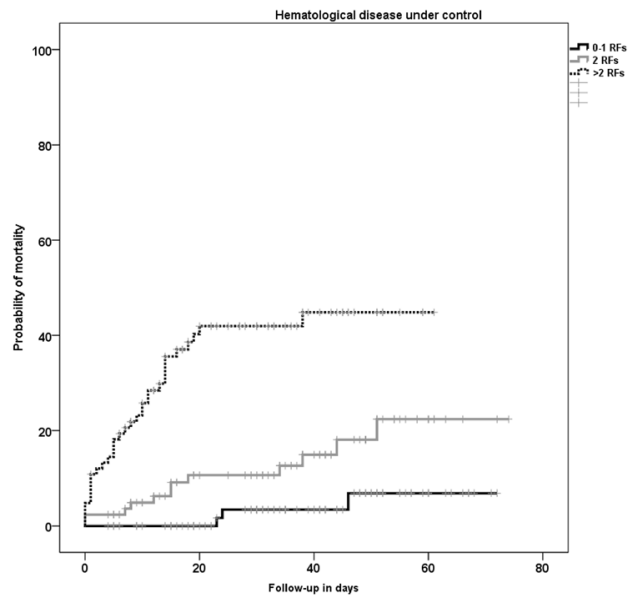

f In non-stem cell transplant (SCT) patients the mortality was $19 \%$ vs. $34 \%$ vs. $54 \%$, respectively $(\boldsymbol{p}<0.0001)$

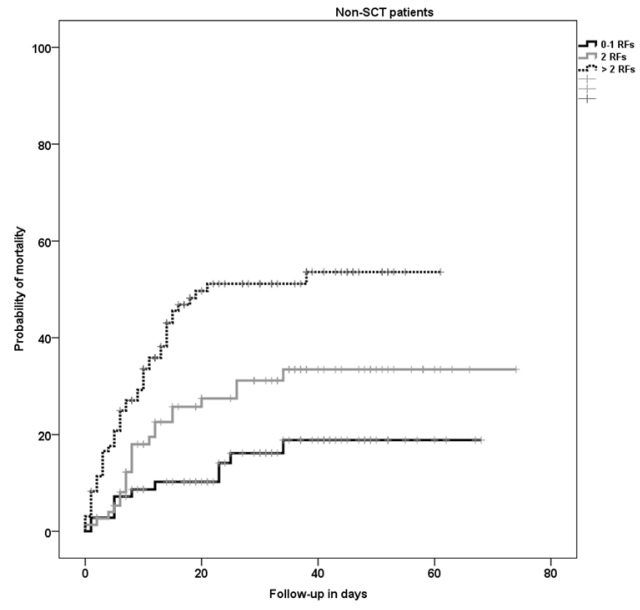


Table 4 Univariate and multivariate analysis of risk factors for COVID-19-related mortality in patients with very severe COVID-19

\begin{tabular}{|c|c|c|c|c|}
\hline \multirow[t]{3}{*}{ Variables } & \multicolumn{4}{|c|}{ Log. Regr. COVID-19 Mortality in patients with COVID-19> stage IIA $(n=216)$} \\
\hline & \multicolumn{2}{|l|}{ Univariate analysis } & \multicolumn{2}{|c|}{ Multivariate analysis } \\
\hline & OR $(95 \% \mathrm{Cl}) \%(95 \% \mathrm{Cl})$ & $\mathbf{p}$ & OR $(95 \% \mathrm{Cl})$ & $\mathbf{p}$ \\
\hline Patient age $>70$ years old & $2.5(1.4-4.3)$ & 0.001 & $2.54(1.2-5.2)$ & 0.011 \\
\hline Patient age & & & ns & \\
\hline $0-20$ & 1 & & & \\
\hline $21-70$ & $0.15(0.017-1.4)$ & 0.11 & & \\
\hline$>70$ & $0.45(0.04-3.9)$ & 0.4 & & \\
\hline Sex male & $1.2(0.43-1.3)$ & 0.3 & & \\
\hline Baseline disease & & & ns & \\
\hline $\mathrm{AML}$ & 1 & & & \\
\hline ALL & $0.5(0.13-1.9)$ & 0.31 & & \\
\hline MDS & $0.48(0.11-1.4)$ & 0.15 & & \\
\hline CMPD & $0.25(0.08-0.76)$ & 0.014 & & \\
\hline $\mathrm{NHL}$ & $0.3(0.12-0.73)$ & 0.008 & & \\
\hline $\mathrm{CLL}$ & $0.11(0.03-0.41)$ & 0.001 & & \\
\hline Plasmatic cell disorder & $0.5(0.2-1.3)$ & 0.18 & & \\
\hline AA or auto-immune disorders & $0.09(0.09-0.89)$ & 0.04 & & \\
\hline \multicolumn{5}{|l|}{ Disease status } \\
\hline $\mathrm{CR} / \mathrm{PR} /$ not requiring therapy & 1 & & & \\
\hline Rel/Ref/Prog & $4.3(2.388-7.8)$ & $<0.0001$ & $3.5(1.6-7.5)$ & 0.001 \\
\hline \multicolumn{5}{|l|}{ Procedure } \\
\hline Allo-SCT & 1 & & & \\
\hline ASCT & $1.08(0.38-3)$ & 0.8 & & \\
\hline Non-SCT & $1.58(0.74-3.3)$ & 0.23 & & \\
\hline Chemotherapy 40 days before COVID-19 & $1.56(0.9-2.7)$ & 0.11 & & \\
\hline Disease Dx within 40 days of COVID-19 & $3.5(1.56-7.8)$ & 0.002 & ns & \\
\hline ECOG 3-4 & $3.1(1.7-5.76)$ & $<0.0001$ & ns & \\
\hline Active smoking & $0.88(0.37-2.1)$ & 0.8 & & \\
\hline Arterial hypertension & $1.97(1.14-.4)$ & 0.014 & $2(1.3-3.2)$ & 0.002 \\
\hline Cardiomyopathy & $1.21(0.6-2.36)$ & 0.56 & & \\
\hline Dyslipidemia & $1.4(0.8 .-2.6)$ & 0.2 & & \\
\hline $\mathrm{ALC}<0.5 \times 10^{9} / \mathrm{L}$ & $1.7(1-3)$ & 0.05 & ns & \\
\hline ANC $<0.5 \times 10^{9} / \mathrm{L}$ & $3.7(1.58-8.7)$ & 0.002 & ns & \\
\hline \multicolumn{5}{|l|}{ Specific therapy } \\
\hline $\mathrm{HCQ}$ & $0.64(0.37-1.1)$ & 0.1 & ns & \\
\hline $\mathrm{AZT}$ & $0.49(0.28-0.84)$ & 0.01 & $0.42(0.2-0.89)$ & 0.02 \\
\hline $\mathrm{HCQ}+\mathrm{AZT}$ & $0.6(0.3-1.2)$ & 0.14 & & \\
\hline lop/rit & $0.7(0.4-1.2)$ & 0.2 & & \\
\hline Remdesivir & $0.18(0.02-1.6)$ & 0.12 & & \\
\hline Corticosteroid therapy & $0.54(0.31-0.93)$ & 0.028 & ns & \\
\hline \multicolumn{5}{|l|}{ Corticosteroid doses } \\
\hline No & 1 & & 1 & \\
\hline$\leq 0.5 \mathrm{mg} / \mathrm{kg} / \mathrm{day}^{\mathrm{b}}$ & $0.44(0.23-0.83)$ & 0.014 & $0.31(0.11-0.87)$ & 0.02 \\
\hline$>0.5 \mathrm{mg} / \mathrm{kg} / \mathrm{day}^{\mathrm{b}}$ & $0.54(0.27-1.06)$ & 0.075 & $0.75(0.34-1.6)$ & 0.4 \\
\hline Cytokine inhibitors & $0.6(0.34-1.1)$ & 0.16 & & \\
\hline Tocilizumab & $0.54(0.28-1.05)$ & 0.073 & ns & \\
\hline \multicolumn{5}{|l|}{ Platelet count $\left(\times 10^{9} / \mathrm{L}\right)$} \\
\hline$\leq 20 \times 10^{9} / \mathrm{L}$ & $6.4(2-19)$ & 0.001 & $5.66(1.44-22)$ & 0.013 \\
\hline
\end{tabular}


Table 4 (continued)

\begin{tabular}{|c|c|c|c|c|}
\hline \multirow[t]{3}{*}{ Variables } & \multicolumn{4}{|c|}{ Log. Regr. COVID-19 Mortality in patients with COVID-19> stage IIA $(n=216)$} \\
\hline & \multicolumn{2}{|l|}{ Univariate analysis } & \multicolumn{2}{|c|}{ Multivariate analysis } \\
\hline & OR $(95 \% \mathrm{Cl}) \%(95 \% \mathrm{Cl})$ & $\mathbf{p}$ & OR $(95 \% \mathrm{Cl})$ & $\mathbf{p}$ \\
\hline $21-50 \times 10^{9} / \mathrm{L}$ & $4.1(1.7-9.7)$ & 0.001 & $3.3(1.2-9.2)$ & 0.021 \\
\hline$>50 \times 10^{9} / \mathrm{L}$ & 1 & & 1 & \\
\hline $\mathrm{CRP}>20 \mathrm{mg} / \mathrm{dL}$ & $2.1(1.08-4.1)$ & 0.027 & $2.7(1.1-6.5)$ & 0.029 \\
\hline $\mathrm{IL}-6>50 \mathrm{pg} / \mathrm{mL}^{\mathrm{a}}$ & $1.8(0.69-4.7)$ & 0.2 & NT & \\
\hline Ferritin levels ${ }^{\mathrm{a}}$ & & & NT & \\
\hline$<500 \mu \mathrm{g} / \mathrm{mL}$ & 1 & & & \\
\hline $501-1000 \mu \mathrm{g} / \mathrm{mL}$ & $0.9(0.2-4.3)$ & 0.9 & & \\
\hline$>1001 \mu \mathrm{g} / \mathrm{mL}$ & $2.2(0.72-7)$ & 0.15 & & \\
\hline D dimer $>500 \mathrm{ng} / \mathrm{mL}^{\mathrm{a}}$ & $1.39(0.76-2.6)$ & 0.2 & NT & \\
\hline
\end{tabular}

SCT: stem cell transplantation; ASCT: autologous stem cell transplantation; allo-SCT: allogeneic hematopoietic stem cell transplantation; AML: acute myeloid leukemia; ALL: acute lymphoblastic leukemia; MDS; myelodysplastic syndrome; CMPD: chronic myeloproliferative disease; NHL: non-Hodgkin lymphoma; CLL: chronic lymphocytic leukemia; AA: aplastic anemia; CR: complete remission; PR: partial remission; Rel: relapse; Ref: refractory; Prog: progression; Dx: diagnostic; ANC: absolute neutrophil count; ALC: absolute lymphocyte count; HCQ: hydroxi-cloroquine; AZT: azithromycin; lop/rit: lopinavir/ritonavir; CRP: C-reactive protein; IL: interleukin; ns: not significant; NT: not tested

a These variables were not included in the multivariate analyses due to the low number of patients with complete data

b Refers to dose of IV methylprednisolone or an equivalent dose of another corticosteroid

many comorbidities who are far from being candidates to the standard-of-care for their AML, MDS, lymphoma, myeloma and other diseases, and patient-specific treatment decisions must commonly be made. In such reallife setting, COVID-19 mortality was mainly driven by advanced age, poor performance status, uncontrolled disease status (not being at least in a partial remission), presence of marrow or immune failure (severe neutropenia, and lymphopenia in the univariate analysis) and having a high baseline and/or COVID-19 induced systemic inflammatory state (identified in the multivariate analysis by high CRP, although high levels of IL-6 and ferritin showed a strong trend in univariate analysis). In contrast, the broad range of hematological malignancies included did not allow us to study the impact of this infection in different diagnoses.

We decided to evaluate the effect of several treatments on mortality only in patients who developed very severe COVID-19 and found that having received azithromycin (AZT) or low-dose corticosteroids were independently associated with lower mortality. Obviously, many clinicians have been using macrolides to treat COVID-19 off-label, without any robust evidence of safety or effectiveness. Our results suggest that the use of azithromycin at least did not have a deleterious impact on survival. In contrast, we found no impact of using hydroxychloroquine (HCQ). To what extend the lack of its benefit could be related to potential severe toxicities or insufficient antiviral activity remains to be determined [39]. Regarding the use of short courses of corticosteroids for COVID-19, prior reports have yielded conflicting results; both favorable [40-43] and detrimental effects $[44,45]$ have been found. A preliminary, unpublished analysis from a large, multicenter, randomized, openlabel trial (RECOVERY study) showed that dexamethasone at $6 \mathrm{mg} /$ day for 10 days reduced the mortality in patients with severe COVID-19 (defined as those who required supplemental oxygen) [46]. Our findings are in line with results from this trial, since $6 \mathrm{mg}$ of dexamethasone is equivalent to $40 \mathrm{mgr}$ of oral prednisone or $32 \mathrm{mgr}$ of IV methylprednisolone, and the latter is within our definition of low-dose steroids $(\leq 0.5 \mathrm{mg} / \mathrm{kg} /$ day methylprednisolone). However, our results should be interpreted with great caution and should not be used to support the use of either azithromycin or low-dose steroids in patients with hematological malignancies. Management of COVID-19 is a worldwide research priority, and the optimal treatment of our patients must be guided by the results of these international randomized clinical trials.

We acknowledge several limitations of this study such as its retrospective nature, the use of different PCR assays and the lack of complete inflammatory markers data in most cases. However, the large number of patients and the comparison between non-SCT and SCT recipients should be considered as its strengths, and a starting point for future larger and more disease-specific or treatmentspecific observational studies. Additionally, our hematological COVID-19 database (see Fig. 1) mirrored national epidemiological data in SARS-CoV-2 during each week [47]. This fact suggests a low probability of bias in reporting hematological COVID-19 cases in our study. 


\section{Conclusions}

COVID-19 was severe in patients with hematological malignancies, and their survival was strongly correlated with the COVID-19 stage and patient and disease-related factors [older age, disease status, performance status, immune (neutropenia) status and systemic inflammation (high CRP)]. However, recipients of a SCT did not have a higher mortality.

\section{Acknowledgements}

REDCap is developed and supported by Vanderbilt Institute for Clinical and Translational Research. We thank the Spanish Society of Hematology $(\mathrm{SEHH})$ for its support on patients' recruitment.

\section{Authors' contributions}

$J\llcorner P$, and RM designed the study and drafted the manuscript. All authors participated in the revision of the manuscript. All authors read and approved the final manuscript.

\section{Funding}

This study has not been funded.

\section{Availability of data and materials}

All data generated or analyzed during this study are included in this published article.

\section{Ethics approval and consent to participate}

All patients gave their informed consent. Local ethics committee approved the study protocol (reference code 2020-113-1), registered by the Spanish Agency of Medicines and Health Products with the reference code GETCLO-2020-01 and by the European Medicines Agency with the reference code EUPAS34365EBMT.

\section{Consent for publication}

The participants provided informed consent for the publication of the study.

\section{Competing interests}

The author(s) declare that they have no conflict of interests.

\section{Author details}

${ }^{1}$ Hematology División, Hospital Universitario y Politécnico La Fe, Instituto de Investigación Sanitaria La Fe, Valencia, Spain. ${ }^{2}$ CIBERONC, Instituto Carlos III, Madrid, Spain. ${ }^{3}$ Hematology División, Hospital de la Santa Creu i Sant Pau, Barcelona, Spain. ${ }^{4}$ Hematology División, Hospital Ramon y Cajal, Madrid, Spain. ${ }^{5}$ Hematology División, Institut Català Oncologia-Hospital Duran i Reynals, Barcelona, Spain. ${ }^{6}$ Hematology División, Hospital de Guadalajara, Guadalajara, Spain. ${ }^{7}$ Hematology División, Hospital La Princesa, Madrid, Spain. ${ }^{8}$ Hematology División, Hospital de Albacete, Albacete, Spain. ${ }^{9}$ Hematology División, Institut Català Oncologia-Hospital Josep Trueta, Girona, Spain. ${ }^{10}$ Hematology División, Hospital Clínico de Valladolid, Valladolid, Spain. ${ }^{11}$ Hematology División, Hospital Carlos Haya, Malaga, Spain. ${ }^{12}$ Hematology División, Hospital Fundación Jiménez Díaz, Madrid, Spain. ${ }^{13}$ Hematology División, Hospital Gregorio Marañon, Madrid, Spain. ${ }^{14}$ Hematology División, Hospital de Navarra, Navarra, Spain. ${ }^{15}$ Hematology División, Hospital a Coruña, Coruña, Spain. ${ }^{16}$ Hematology División, Hospital Virgen de la Nieves, Granada, Spain. ${ }^{17}$ Hematology División, Hospital 12 de Octubre, Madrid, Spain. ${ }^{18}$ Hematology División, Hospital Universitario de Salamanca, Salamanca, Spain. ${ }^{19}$ Hematology División, Hospital Vall d’Hebron, Barcelona, Spain. ${ }^{20}$ Hematology División, Hospital Clínico Universitario Lozano Blesa, IIS Aragon, Zaragoza, Spain. ${ }^{21}$ Hematology División, Hospital Puerta de Hierro, Madrid, Spain. ${ }^{22}$ Hematology División, Hospital de Vigo, Vigo, Spain. ${ }^{23}$ Hematology División, Hospital General de Alicante, Alicante, Spain. ${ }^{24}$ Hematology División, Hospital de Donostia, Donostia, Spain. ${ }^{25}$ Hematology División, Hospital Clínico Universitario de Valencia, Valencia, Spain. ${ }^{26}$ Hematology División, Hospital Arnau de Vilanova, Valencia, Spain. ${ }^{27}$ Department of Hematology, University Hospital Virgen del Rocío/University of Sevilla, CSIC/Institute of Biomedicine of Sevilla, Sevilla, Spain. ${ }^{28}$ Hematology División, Hospital de Jerez, Jerez, Spain. ${ }^{29}$ Pediatric Hematology-Oncology División, Hospital la Paz, Madrid, Spain. ${ }^{30}$ Hematology
División, ICO-Hospital Germans Trias i Pujol, Josep Carreras Research Institute, Badalona, Spain. ${ }^{31}$ Pediatric División, Hospital de la Santa Creu i Sant Pau, Barcelona, Spain. ${ }^{32}$ Pediatric División, Hospital niño Jesús, Madrid, Spain.

${ }^{33}$ Hematology División, Hospital Marqués de Valdecilla, Santander, Spain.

${ }^{34}$ Hematology División, Hospital Joan XXIII, Tarragona, Spain. ${ }^{35}$ Hematopoietic Stem Cell Transplantation and Cell Therapy Group (GETH), Madrid, Spain.

${ }^{36}$ Division of Clinical Hematology, Hospital Universitario la Fe de Valencia, Avda Fernando Abril Martorell, 106 CP 46026 Valencia, Spain.

Received: 16 July 2020 Accepted: 18 August 2020

Published online: 25 August 2020

\section{References}

1. Guan W, Ni Z, Yu Hu, Liang W, Ou C, He J, Liu L, Shan H, Lei C, Hui DSC, et al. Clinical characteristics of coronavirus disease 2019 in China. N Engl J Med. 2020;382:1708-20.

2. Yang $X, Y u Y, X u$ J, Shu H, Liu H, Wu Y, Zhang L, Yu Z, Fang M, Yu T, Wang $Y$, et al. Clinical course and outcomes of critically ill patients with SARSCoV-2 pneumonia in Wuhan, China: a single-centered, retrospective, observational study. Lancet Respir Med. 2020. https://doi.org/10.1016/ S2213-2600(20)30079-5

3. Zhou F, Yu T, Du R, Fan G, Liu Y, Liu Z, Xiang J, Wang Y, Song B, Gu X, et al. Clinical course and risk factors for mortality of adult inpatients with COVID-19 in Wuhan, China: a retrospective cohort study. Lancet. 2020;395:1054-62.

4. Yang Jing, Zheng Ya, Gou Xi, Ke Pu, Chen Zhaofeng, Guo Qinghong, Ji Rui, Wang Haojia, Wang Yuping, Zhou Yongning. Prevalence of comorbidities in the novel Wuhan coronavirus (COVID-19) infection: a systematic review and meta-analysis. Int J Infect Dis. 2020. https://doi.org/10.1016/j. ijid.2020.03.017.

5. Chien JW, Martin PJ, Gooley TA, Flowers ME, Heckbert SR, Nichols WG, Clark JG. Airflow obstruction after myeloablative allogeneic hematopoietic stem cell transplantation. Am J Respir Crit Care Med. 2003;168(2):208-14

6. Erard V, Chien JW, Kim HW, Nichols WG, Flowers ME, Martin PJ, Corey L, Boeckh M. Airflow decline after myeloablative allogeneic hematopoietic cell transplantation: the role of community respiratory viruses. J Infect Dis. 2006;193(12):1619-25.

7. Liang W, Guan W, Chen R, Wang W, Li J, Xu K, Li C, Ai Q, Lu W, Liang H, et al Cancer patients in SARS-CoV-2 infection: a nationwide analysis in China. Lancet Oncol. 2020;21:335-7.

8. Dai M, Liu D, Liu M, Zhou F, Li G, Chen Z, Zhang Z, You H, Wu M, Zheng $\mathrm{Q}$, et al. Patients with cancer appear more vulnerable to SARS-CoV-2: a multicenter study during the COVID-19 outbreak. Cancer Discov. 2020. https://doi.org/10.1158/2159-8290.cd-20-0422 (published online April 28).

9. Miyashita H, Mikami T, Chopra N, Yamada T, Chernyavsky S, Rizk D, Cruz C. Do patients with cancer have a poorer prognosis of COVID-19? An experience in New York City. Ann Oncol. 2020. https://doi.org/10.1016/j.annon c.2020.04.006 (published online April 21).

10. Malard F, Genthon A, Brissot E, van de Wyngaert Z, Marjanovic Z, Ikhlef S, Banet A, Lapusan S, Sestilli S, Corre E, et al. COVID-19 outcomes in patients with hematologic disease. Bone Marrow Transplant. 2020. https ://doi.org/10.1038/s41409-020-0931-4.

11. Martín-Moro F, Marquet J, Piris M, Michael BM, Sáez AJ, Corona M, Jiménez C, Astibia B, García I, Rodríguez E, et al. Survival study of hospitalised patients with concurrent COVID-19 and haematological malignancies. $\mathrm{Br}$ J Haematol. 2020. https://doi.org/10.1111/bjh.16801.

12. Scarfò L, Chatzikonstantinou T, Rigolin GM, Quaresmini G, Motta M, Vitale C, Garcia-Marco JA, Hernández-Rivas JÁ, Mirás F, Baile M, et al. COVID-19 severity and mortality in patients with chronic lymphocytic leukemia: a joint study by ERIC, the European Research Initiative on CLL, and CLL Campus. Leukemia. 2020. https://doi.org/10.1038/s41375-020-0959-x.

13. Mehta Vikas, Goel Sanjay, Kabarriti Rafi, Cole Daniel, Goldfinger Mendel, Acuna-Villaorduna Ana, Pradhan Kith, Thota Raja, Reissman Stan, Sparano Joseph A, et al. Case fatality rate of cancer patients with COVID-19 in a New York Hospital System. Cancer Discov. 2020;10(7):935-41. https://doi. org/10.1158/2159-8290.CD-20-0516. 
14. Wang B, Van Oekelen O, Mouhieddine TH, Del Valle DM, Richter J, Cho HJ, Richard S, Chari A, Gnjatic S, Merad M, et al. A tertiary center experience of multiple myeloma patients with COVID-19: lessons learned and the path forward. J Hematol Oncol. 2020;13:94.

15. Siddiqi HK, Mehra MR. COVID-19 illness in native and immunosuppressed states: a clinical-therapeutic staging proposal. J Heart Lung Transplant. 2020;39:405-7.

16. Döhner H, Estey E, Grimwade D, Amadori S, Appelbaum FR, Büchner T, Dombret $\mathrm{H}$, Ebert BL, Fenaux P, Larson RA, et al. Diagnosis and management of AML in adults: 2017 ELN recommendations from an international expert panel. Blood. 2017;129(4):424-47. https://doi.org/10.1182/blood -2016-08-733196.

17. Cheson BD, Fisher RI, Barrington SF, Cavalli F, Schwartz LH, Zucca E, Lister TA; Alliance, Australasian Leukaemia and Lymphoma Group; Eastern Cooperative Oncology Group; European Mantle Cell Lymphoma Consortium; Italian Lymphoma Foundation; European Organisation for Research; Treatment of Cancer/Dutch Hemato-Oncology Group; Grupo Español de Médula Ósea; German High-Grade Lymphoma Study Group; German Hodgkin's Study Group; Japanese Lymphorra Study Group; Lymphoma Study Association; NCIC Clinical Trials Group; Nordic Lymphoma Study Group; Southwest Oncology Group; United Kingdom National Cancer Research Institute. Recommendations for initial evaluation, staging, and response assessment of Hodgkin and non-Hodgkin lymphoma: the Lugano classification. J Clin Oncol. 2014 Sep 20;32(27):3059-68.

18. Kumar S, Paiva B, Anderson KC, Durie B, Landgren O, Moreau P, Munshi N, Lonial S, Bladé J, Mateos MV, et al. International Myeloma Working Group consensus criteria for response and minimal residual disease assessment in multiple myeloma. Lancet Oncol. 2016;17(8):e328-46. https://doi. org/10.1016/S1470-2045(16)30206-6.

19. Oken MM, Creech RH, Tormey DC, Horton J, Davis TE, McFadden ET, Carbone PP. Toxicity and response criteria of the Eastern Cooperative Oncology Group. Am J Clin Oncol. 1982;5:649-55.

20. Lapostolle F, Schneider E, Vianu I, Dollet G, Roche B, Berdah J, Michel J, Goix L, Chanzy E, Petrovic T, et al. Clinical features of 1487 COVID-19 patients with outpatient management in the Greater Paris: the COVIDcall study. Intern Emerg Med. 2020. https://doi.org/10.1007/s11739-02002379-Z (Epub ahead of print).

21. Hao S, Lian J, Lu Y, Jia H, Hu J, Yu G, Wang X, Xu K, Ni Q, Li Y, et al. Decreased $B$ cells on admission was associated with prolonged viral RNA shedding from respiratory tract in Coronavirus Disease 2019: a case control study. J Infect Dis. 2020. https://doi.org/10.1093/infdis/jiaa311 (Epub ahead of print).

22. Wang Y, Kang H, Liu X, Tong Z. Asymptomatic cases with SARS-CoV-2 infection. J Med Virol. 2020. https://doi.org/10.1002/jmv.25990 (Epub ahead of print).

23. Division of Risk Assessment and International Cooperation. The updates on COVID-19 in Korea as of April 17. Korea Centers for Disease Control \& Prevention, 2020.

24. Nishiura H, Kobayashi T, Miyama T, Suzuki A, Jung SM, Hayashi K, Kinoshita $R$, Yang Y, Yuan B, Akhmetzhanov AR, Linton NM. Estimation of the asymptomatic ratio of novel coronavirus infections (COVID-19). Int J Infect Dis. 2020;94:154-5.

25. Arons MM, Hatfield KM, Reddy SC, Kimball A, James A, Jacobs JR, Taylor J, Spicer K, Bardossy AC, Oakley LP, et al. Presymptomatic SARS-CoV-2 infections and transmission in a skilled nursing facility. N Engl J Med. 2020;382:2081-90.

26. Zou L, Ruan F, Huang M. SARS-CoV-2 viral load in upper respiratory specimens of infected patients. N Engl J Med. 2020;382:1177-9.

27. Shah DP, Ghantoji SS, Mulanovich VE, Ariza-Heredia EJ, Chemaly RF. Management of respiratory viral infections in hematopoietic cell transplant recipients. Am J Blood Res. 2012;2(4):203-18 (Epub 2012 Nov 25).

28. Zhou P, Yang XL, Wang XG, Hu B, Zhang L, Zhang W, Si HR, Zhu Y, Li B, Huang $\mathrm{CL}$, et al. A pneumonia outbreak associated with a new coronavirus of probable bat origin. Nature. 2020;579:270-3.

29. Hoffmann M, Kleine-Weber H, Schroeder S, Kruger N, Herrler T, Erichsen S, Schiergens TS, Herrler G, Wu NH, Nitsche A, et al. SARS-CoV-2 cell entry depends on ACE2 and TMPRSS2 and is blocked by a clinically proven protease inhibitor. Cell. 2020. https://doi.org/10.1016/j.cell.2020.02.052.

30. Huang C, Wang Y, Li X, Ren L, Zhao J, Hu Y, Zhang L, Fan G, Xu J, Gu X, et al. Clinical features of patients infected with 2019 novel coronavirus in Wuhan, China. Lancet. 2020;395:497-506.

31. Wan S, Xiang Y, Fang W, Zheng Y, Li B, Hu Y, Lang C, Huang D, Sun Q, Xiong $Y$, et al. Clinical features and treatment of COVID-19 patients in northeast Chongqing. J Med Virol. 2020;92(7):797-806.

32. Zhang JJ, Dong X, Cao YY, Yuan YD, Yang YB, Yan YQ, Akdis CA, Gao YD. Clinical characteristics of 140 patients infected with SARS-CoV-2 in Wuhan, China. Allergy. 2020. https://doi.org/10.1111/all.14238.

33. Piñana JL, Pérez A, Montoro J, Hernani R, Lorenzo I, Giménez E, Gómez MD, Guerreiro M, González-Barberá EM, Carretero C, et al. The effect of timing on community acquired respiratory virus infection mortality during the first year after allogeneic hematopoietic stem cell transplantation: a prospective epidemiological survey. Bone Marrow Transplant. 2020;55(2):431-40.

34. Wu C, Chen X, Cai Y, Xia J, Zhou X, Xu S, Huang H, Zhang L, Zhou X, Du C, et al. Risk Factors Associated With Acute Respiratory Distress Syndrome and Death in Patients With Coronavirus Disease 2019 Pneumonia in Wuhan, China. JAMA Internal Medicine. 2020. https://doi.org/10.1001/ jamainternmed.2020.0994.

35. Bhargava A, Fukushima EA, Levine M, Zhao W, Tanveer F, Szpunar SM, Saravolatz L. Predictors for severe COVID-19 infection. Clin Infect Dis. 2020. https://doi.org/10.1093/cid/ciaa674.

36. Chen W, Zheng KI, Liu S, Yan Z, Xu C, Qiao Z. Plasma CRP level is positively associated with the severity of COVID-19. Ann Clin Microbiol Antimicrob. 2020;19(1):18.

37. Kuderer NM, Choueiri TK, Shah DP, Shyr Y, Rubinstein SM, Rivera DR, Shete S, Hsu CY, Desai A, de Lima Lopes G Jr, et al. COVID-19 and Cancer Consortium. Clinical impact of COVID-19 on patients with cancer (CCC19): a cohort study. Lancet. 2020. https://doi.org/10.1016/s0140-6736(20)31187-9.

38. Wu Z, McGoogan JM. Characteristics of and important lessons from the coronavirus disease 2019 (COVID-19) outbreak in China: summary of a report of 72314 cases from the Chinese Center for Disease Control and Prevention. JAMA. 2020. https://doi.org/10.1001/jama.2020.2648.

39. Rosenberg ES, Dufort EM, Udo T, Wilberschied LA, Kumar J, Tesoriero J, Weinberg P, Kirkwood J, Muse A, DeHovitz J, et al. Association of Treatment With Hydroxychloroquine or Azithromycin With InHospital Mortality in Patients With COVID-19 in New York State. JAMA. 2020;323(24):2493-502. https://doi.org/10.1001/jama.2020.8630.

40. Kolilekas L, Loverdos K, Giannakaki S, Vlassi L, Levounets A, Zervas E, Gaga M. Can steroids reverse the severe COVID-19 induced 'cytokine storm'? J Med Virol. 2020. https://doi.org/10.1002/jmv.26165.

41. Fadel R, Morrison AR, Vahia A, Smith ZR, Chaudhry Z, Bhargava P, Miller J, Kenney RM, Alangaden G, Ramesh MS. Henry Ford COVID-19 Management Task Force Early short course corticosteroids in hospitalized patients with COVID-19. Clin Infect Dis. 2020. https://doi.org/10.1093/cid/ciaa601.

42. So C, Ro S, Murakami M, Imai R, Jinta T. High-dose, short-term corticosteroids for ARDS caused by COVID-19: a case series. Respirol Case Rep. 2020;8(6):e00596.

43. Wu C, Chen X, Cai Y, Xia J, Zhou X, Xu S, Huang H, Zhang L, Zhou X, Du C, et al. Risk factors associated with acute respiratory distress syndrome and death in patients with coronavirus disease 2019 pneumonia in Wuhan. China. JAMA Intern Med. 2020;180(7):1-11.

44. Yuan M, Xu X, Xia D, Tao Z, Yin W, Tan W, Hu Y, Song C. Effects of corticosteroid treatment for non-severe COVID-19 pneumonia: a propensity score-based analysis. Shock. 2020. https://doi.org/10.1097/SHK.00000 00000001574.

45. Yang Z, Liu J, Zhou Y, Zhao X, Zhao Q, Liu J. The effect of corticosteroid treatment on patients with coronavirus infection: a systematic review and meta-analysis. J Infect. 2020;81(1):e13-20.

46. Randomised Evaluation of COVID-19 Therapy (RECOVERY). Low-cost dexamethasone reduces death by up to one third in hospitalised patients with severe respiratory complications of COVID-19. 2020. Available at: https://www.recoverytrial.net/news/low-cost-dexamethasone-reduc 
es-death-by-up-to-one-third-in-hospitalised-patients-with-severe-respi ratory-complications-of-covid-19. Accessed June 23, 2020.

47. Actualización no 130. Enfermedad por el coronavirus (COVID-19).

08.06.2020. https://www.mscbs.gob.es/profesionales/saludPublica/ccayes/ alertasActual/nCov-China/documentos/Actualizacion_130_COVID-19.pdf.

\section{Publisher's Note}

Springer Nature remains neutral with regard to jurisdictional claims in published maps and institutional affiliations.
Ready to submit your research? Choose BMC and benefit from:

- fast, convenient online submission

- thorough peer review by experienced researchers in your field

- rapid publication on acceptance

- support for research data, including large and complex data types

- gold Open Access which fosters wider collaboration and increased citations

- maximum visibility for your research: over 100M website views per year

At BMC, research is always in progress.

Learn more biomedcentral.com/submissions 